Article

\title{
A novel process of ozone catalytic oxidation for low concentration formaldehyde removal
}

\author{
Bin Zhu a,b,c, Xiao-Song Li b,c, Peng Sun b,c, Jing-Lin Liu b,c, Xiao-Yuan Ma b,c, Xiaobing Zhu b,c,*, \\ Ai-Min Zhu b,c,\# \\ a Collaborative Innovation Center for Vessel Pollution Monitoring and Control, Dalian Maritime University, Dalian 116026, Liaoning, China \\ b Laboratory of Plasma Physical Chemistry, Dalian University of Technology, Dalian 116024, Liaoning, China \\ c Center for Hydrogen Energy \& Environmental Catalysis, Dalian University of Technology, Dalian 116024, Liaoning, China
}

\section{A R T I C L E I N F O}

\section{Article history:}

Received 2 June 2017

Accepted 19 July 2017

Published 5 October 2017

\section{Keywords:}

Formaldehyde removal

Storage

Ozone

Catalytic oxidation

Manganese oxide catalyst

\begin{abstract}
A B S T R A C T
To reduce energy costs, minimize secondary pollution from undecomposed ozone, and improve the efficiency of ozone use, a novel process of cycled storage-ozone catalytic oxidation (OZCO) was employed to remove formaldehyde (HCHO) at low concentrations in air. We applied $\mathrm{Al}_{2} \mathrm{O}_{3}$-supported manganese oxide $\left(\mathrm{MnO}_{x}\right)$ catalysts to this process, and examined the $\mathrm{HCHO}$ adsorption capacity and OZCO performance over the $\mathrm{MnO}_{x}$ catalysts. Owing to the high dispersion of $\mathrm{MnO}_{x}$ and low oxidation state of manganese, the $\mathrm{MnO}_{x} / \mathrm{Al}_{2} \mathrm{O}_{3}$ catalysts with a manganese acetate precursor and 10\%-Mn loading showed good performance in both storage and OZCO stages. The presence of $\mathrm{H}_{2} \mathrm{O}$ led to a decrease of the $\mathrm{HCHO}$ adsorption capacity owing to competitive adsorption between moisture and $\mathrm{HCHO}$ at the storage stage; however, high relative humidity (RH) favored complete conversion of stored $\mathrm{HCHO}$ to $\mathrm{CO}_{2}$ at the OZCO stage and contributed to an excellent carbon balance. Four low concentration HCHO storage-OZCO cycles with a long HCHO storage period and relatively short OZCO period were successfully performed over the selected $\mathrm{MnO}_{x} / \mathrm{Al}_{2} \mathrm{O}_{3}$ catalyst at room temperature and a $\mathrm{RH}$ of $50 \%$, demonstrating that the proposed storage-OZCO process is an economical, reliable, and promising technique for indoor air purification.
\end{abstract}

(C) 2017, Dalian Institute of Chemical Physics, Chinese Academy of Sciences. Published by Elsevier B.V. All rights reserved.

\section{Introduction}

Indoor air quality has become a serious issue owing to the increasing amount of time people spent indoors. Formaldehyde (HCHO) is a common volatile organic compound (VOC) presence in indoor air, which poses serious risks to human health $[1,2]$. Thus, removal of indoor HCHO has attracted considerable attention in the field of environment protection. Various methods of air purification, including catalytic oxidation [3-5], photocatalytic oxidation [6,7], and plasma oxidation [8,9] have been investigated for elimination of HCHO from air. However, considering the low concentration and long-term release of HCHO in indoor environments, most air purification methods are unsuitable for practical applications to indoor HCHO removal owing to their high operating temperatures and requirements for expensive noble metals [10-12].

Recently, ozone catalytic oxidation (OZCO), which involves reactions between active species from ozone, such as active

\footnotetext{
* Corresponding author. Tel/Fax: +86-411-84706094; E-mail: xzhu@dlut.edu.cn

\# Corresponding author. Tel/Fax: +86-411-84706094; E-mail: amzhu@dlut.edu.cn

This work was supported by the National Natural Science Foundation of China (21673030) and the Higher Education Development Fund (for Collaborative Innovation Center) of Liaoning Province, China (20110217004).

DOI: 10.1016/S1872-2067(17)62890-0 | http://www.sciencedirect.com/science/journal/18722067 | Chin. J. Catal., Vol. 38, No. 10, October 2017
} 
oxygen atoms and hydroxyl radicals, and adsorbed VOCs can readily proceed at room temperature without the use of noble metal catalysts. This method is regarded as a promising alternative technique for low temperature oxidation of VOCs [13-15]. Great efforts have been devoted to the elimination of benzene [16-18], toluene [19,20], and formaldehyde [21] by the OZCO approach. In our previous work, we demonstrated that ozone can completely oxidize $\mathrm{HCHO}$ into $\mathrm{CO}_{2}$ and $\mathrm{H}_{2} \mathrm{O}$ over a manganese oxide $\left(\mathrm{MnO}_{x}\right)$ catalyst at room temperature [22]. Supported $\mathrm{MnO}_{x}$ is the most commonly used catalyst in OZCO of VOCs because of its superior ozone decomposition ability [23-26]. Nevertheless, the utilization of ozone in a conventional OZCO reaction is greatly depressed because HCHO is normally present at low concentrations indoors. This might lead to energy wasted on ozone production and cause secondary pollution owing to a continuous exhaust of incompletely decomposed ozone into the air.

To improve ozone utilization, effectively reduce energy costs, and minimize secondary pollution caused by undecomposed ozone during the HCHO removal process, in this work we used a cycled storage-OZCO approach to eliminate HCHO. The cycled HCHO storage-OZCO process was conducted over a supported $\mathrm{MnO}_{x} / \mathrm{Al}_{2} \mathrm{O}_{3}$ catalyst at room temperature and included two stages, namely, a HCHO storage stage and an OZCO stage. In the storage stage, a low concentration of $\mathrm{HCHO}$ in the air was first adsorbed on the $\mathrm{MnO}_{x} / \mathrm{Al}_{2} \mathrm{O}_{3}$ surface. Subsequently, at the OZCO stage, stored species, including formate and dioxymethylene (DOM), from HCHO adsorption were converted into $\mathrm{CO}_{2}$ and $\mathrm{H}_{2} \mathrm{O}$ by ozone oxidization [27]. The $\mathrm{MnO}_{x} / \mathrm{Al}_{2} \mathrm{O}_{3}$ adsorption sites were regenerated to allow further storage in the next cycle. This storage-OZCO process offers two main advantages for overcoming the limitations encountered by conventional continuous OZCO methods. First, ozone is supplied only at the OZCO stage; thus, the consumption of ozone and associated energy costs are considerably reduced. Second, at the OZCO stage, a large amount of surface species, accumulated during the storage stage, can react with oxidative species from ozone decomposition effectively over a relatively short period. This effect not only facilitates an improvement of ozone utilization compared with the continuous OZCO reaction, but also considerably reduces pollution caused by undecomposed ozone. Therefore, we expect that cycled storage-OZCO processes could be used for indoor HCHO purification. To the best of our knowledge, the removal of low concentrations of HCHO using a cycled storage-OZCO process has not yet been reported.

\section{Experimental}

\subsection{Catalyst preparation}

In this work, $\gamma-\mathrm{Al}_{2} \mathrm{O}_{3}$ supported $\mathrm{MnO}_{x}$ catalysts were prepared by an incipient wetness impregnation method. To examine the effects of the manganese precursor, manganese(II) nitrate (mass fraction $50 \%, \mathrm{Mn}\left(\mathrm{NO}_{3}\right)_{2}$ ) and manganese(II) acetate $\left(\mathrm{Mn}\left(\mathrm{CH}_{3} \mathrm{COO}\right)_{2}\right)$ were used as the precursors. The impregnated samples were first aged at room temperature for $15 \mathrm{~h}$, and then dried at $110{ }^{\circ} \mathrm{C}$ for $6 \mathrm{~h}$. The dried samples were then calcined at $500{ }^{\circ} \mathrm{C}$ for $4 \mathrm{~h}$ in air to obtain fresh $\mathrm{MnO}_{x} / \mathrm{Al}_{2} \mathrm{O}_{3}$ catalysts.

\subsection{Catalyst characterization}

The phase composition of the $\mathrm{MnO}_{x} / \mathrm{Al}_{2} \mathrm{O}_{3}$ catalysts was identified by X-ray diffraction (XRD) with use of a PANalytical Empyrean diffractometer with a $\mathrm{Cu} K_{\alpha}$ radiation source. The XRD patterns were collected in the $2 \theta$ range of $20^{\circ}-80^{\circ}$ at a scanning rate of $5^{\circ} / \mathrm{min}$ with $\mathrm{Cu} K_{\alpha}$ radiation $(\lambda=0.154 \mathrm{~nm})$ at $40 \mathrm{kV}$ and $40 \mathrm{~mA}$. Brunauer-Emmett-Teller (BET) surface areas of the catalysts were measured by $\mathrm{N}_{2}$ adsorption-desorption isotherms at $-196^{\circ} \mathrm{C}$ (Micromeritics ASAP 2020 V3.01, USA). Before the measurements, the samples were first pretreated at $350{ }^{\circ} \mathrm{C}$ for $10 \mathrm{~h}$ under vacuum. X-ray photoelectron spectroscopy (XPS; ESCALAB250 ThermoVG, USA) was performed with an $\mathrm{Al} K_{\alpha} \mathrm{X}$-ray source (1486.6 eV), operated at $15 \mathrm{kV}$ and 300 $\mathrm{W}$, to examine the surface chemical states of the $\mathrm{MnO}_{x} / \mathrm{Al}_{2} \mathrm{O}_{3}$ catalysts. The samples were first outgassed overnight under a vacuum of $10^{-5} \mathrm{~Pa}$ and then tested in the analytical chamber of the XPS spectrometer under $10^{-8} \mathrm{~Pa}$. The binding energies were calibrated against the XPS spectra of the $\mathrm{C} 1 s$ peak at $284.6 \mathrm{eV}$. Temperature programmed oxidation (TPO) experiments were performed over the catalysts after one HCHO storage-OZCO cycle. The used catalysts were first purged with a dry simulated air stream $\left(20 \% \mathrm{O}_{2}\right.$ balance $\left.\mathrm{N}_{2}\right)$ at a flow rate of $250 \mathrm{~mL} / \mathrm{min}$ at room temperature for 30 min before the TPO test. Subsequently, a temperature programed course was performed in simulated air $(100 \mathrm{~mL} / \mathrm{min})$ from room temperature to $350{ }^{\circ} \mathrm{C}$ with a constant rate of $5{ }^{\circ} \mathrm{C} / \mathrm{min}$. The gas products were monitored online with a $\mathrm{CO}_{x}$ analyzer (S710, SICK/MAIHAK, Germany).

Diffuse reflectance infrared Fourier-transform (DRIFT) spectra of the $\mathrm{MnO}_{x} / \mathrm{Al}_{2} \mathrm{O}_{3}$ catalysts during the cycled $\mathrm{HCHO}$ storage-OZCO process were recorded by an FT-IR spectrometer (Nicolet 6700, Thermo Fisher, USA) with an MCT detector operated at a resolution of $4 \mathrm{~cm}^{-1}$ from 4000 to $1000 \mathrm{~cm}^{-1}$. Fresh $\mathrm{MnO}_{x} / \mathrm{Al}_{2} \mathrm{O}_{3}$ samples were placed in a DRIFT cell (equipped with $\mathrm{KBr}$ windows) and pretreated with $200 \mathrm{~mL} / \mathrm{min} \mathrm{Ar}$ at 500 ${ }^{\circ} \mathrm{C}$ for $2 \mathrm{~h}$ and then cooled down to room temperature. Before the DRIFT measurements, the samples were further treated with $200 \mathrm{~mL} / \mathrm{min}$ simulated air (containing $150 \mathrm{ppm} \mathrm{O}_{3}$ ) for 1 h. The background reference was collected with a fresh $\mathrm{MnO}_{x} / \mathrm{Al}_{2} \mathrm{O}_{3}$ sample at room temperature in simulated air $(200$ $\mathrm{mL} / \mathrm{min}$ ). Subsequently, two HCHO storage-OZCO cycles were conducted. At the storage stage, $200 \mathrm{~mL} / \mathrm{min}$ of simulated air (containing $15 \mathrm{ppm} \mathrm{HCHO}$ ) was flowed through the catalyst for $1 \mathrm{~h}$. At the OZCO stage, $200 \mathrm{~mL} / \mathrm{min}$ of simulated air (containing $150 \mathrm{ppm} \mathrm{O}_{3}$ ) was used to oxidize the catalyst for $30 \mathrm{~min}$.

\subsection{Catalytic performance measurement for $\mathrm{HCHO}$ storage-OZCO process}

Fig. 1 illustrates a schematic diagram of the experimental setup used in the cycled storage-OZCO process. The HCHO used in this work was produced by depolymerization of trioxymethylene vapor in a $\mathrm{N}_{2}$-diluted gas stream. The depolymerization reaction was conducted at $160^{\circ} \mathrm{C}$ over glass pellets coated with 

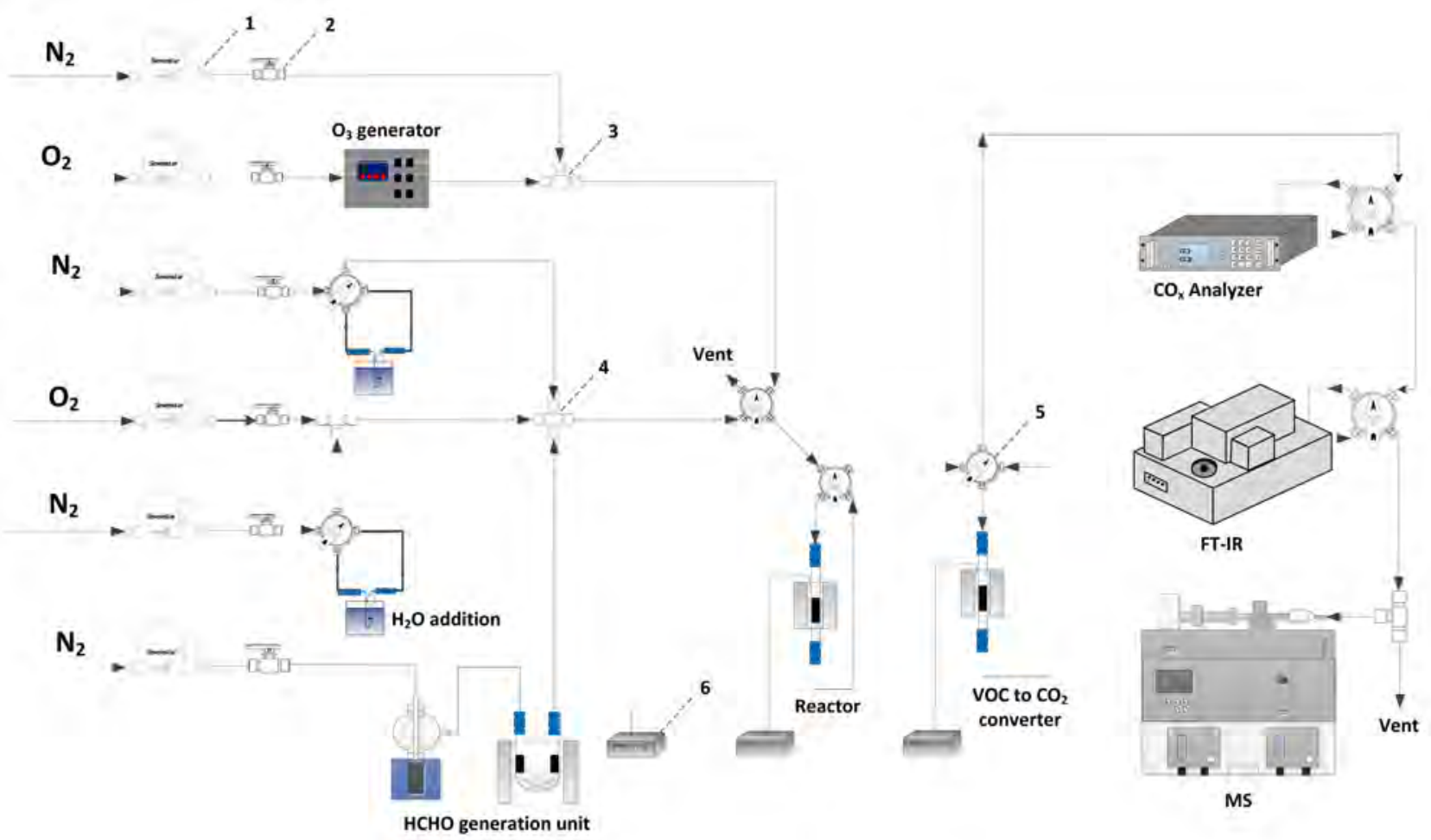

Fig. 1. Schematic diagram of the experimental setup for the cycled storage-OZCO process. (1) Mass flow controller; (2) Valve; (3) Three-way union; (4) Four-way union; (5) Four-way valve; (6) Temperature controller.

85\% phosphoric acid [28]. The HCHO was completely converted into $\mathrm{CO}_{2}$ by a homemade VOC-to- $\mathrm{CO}_{2}$ converter $\left(10 \% \mathrm{Cu} / 10 \% \mathrm{Mn} / \gamma-\mathrm{Al}_{2} \mathrm{O}_{3}\right.$ catalyst $)$ at $400{ }^{\circ} \mathrm{C}$ to measure its concentration, and the $\mathrm{CO}_{2}$ concentration was monitored by the $\mathrm{CO}_{x}$ analyzer and used to determine the initial HCHO concentration in the feed gas. Ozone was generated from pure $\mathrm{O}_{2}$ with a home-made ozone generator [24,28], and its concentration was tested online with a FT-IR spectrometer (IGS, Thermofisher, USA) equipped with a gas cell with an optical path length of $2 \mathrm{~m}$. The gas flow rates were controlled by mass flow controllers (Seven Star Co., China). The amount of water in the gas was adjusted by changing the flow rates of the carrier gas which flowed through a water bubbler, measured online with a dew point hygrometer (653-2, Testo, Germany) and expressed as relative humidity $(\mathrm{RH})$ at $23^{\circ} \mathrm{C}$.

A schematic diagram of the cycled storage-OZCO process for HCHO removal is shown in Fig. 2. Experiments were conducted in a one-way flow fixed-bed quartz reactor $(8 \mathrm{~mm}$ internal di-

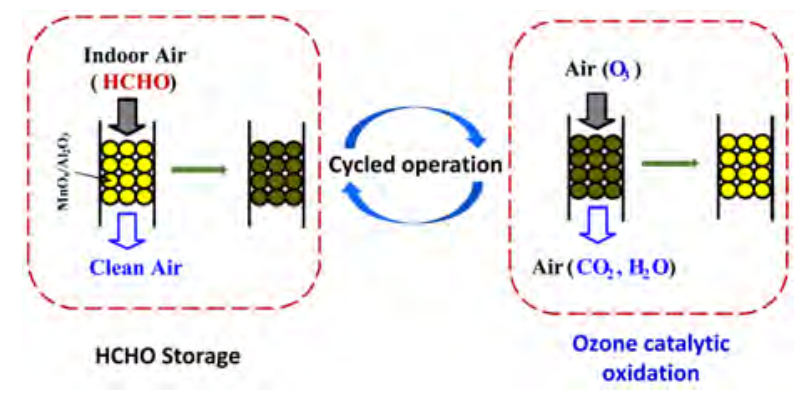

Fig. 2. Schematic diagram of the cycled storage-OZCO process for indoor HCHO removal. ameter) at room temperature and atmospheric pressure. A 1-mL portion of the $\mathrm{MnO}_{x} / \mathrm{Al}_{2} \mathrm{O}_{3}$ catalyst was loaded into the tube reactor. Before the storage experiment, $\mathrm{MnO}_{x} / \mathrm{Al}_{2} \mathrm{O}_{3}$ was first pretreated with $250 \mathrm{~mL} / \mathrm{min}$ stimulated air for $2 \mathrm{~h}$ at 500 ${ }^{\circ} \mathrm{C}$ and then switched to $150 \mathrm{ppm}$ of ozone in simulated air streams $(250 \mathrm{~mL} / \mathrm{min})$ for $1 \mathrm{~h}$. At the storage stage, a low concentration of HCHO in simulated air (containing 15 ppm HCHO) with $450 \mathrm{~mL} / \mathrm{min}$ flowed through the catalyst bed at a gas hourly space velocity (GHSV) of $27000 \mathrm{~h}^{-1}$. During the OZCO stage, a gas mixture $(250 \mathrm{~mL} / \mathrm{min})$ of $150 \mathrm{ppm} \mathrm{O}_{3}, 20 \% \mathrm{O}_{2}$, balance $\mathrm{N}_{2}$ was used to oxidize the catalyst bed at a GHS of $15000 \mathrm{~h}^{-1}$, and the outlet gaseous products were analyzed online by the $\mathrm{CO}_{x}$ analyzer and FT-IR spectrometer.

According to our previous works [27-29], the HCHO breakthrough capacity $\left(n_{\mathrm{b}}\right)$, carbon balance $\left(B_{\mathrm{C}}\right)$ and selectivity for $\mathrm{CO}\left(S_{\mathrm{CO}}\right)$ and $\mathrm{CO}_{2}\left(S_{\mathrm{CO} 2}\right)$ were defined as follows:

$$
\begin{gathered}
n_{\mathrm{b}}=C_{\mathrm{HCHO}} F_{1} t_{\mathrm{b}} / V_{\text {cat. }} \\
B_{\mathrm{C}}=\left(n_{\mathrm{CO}, \text { produced }}+n_{\mathrm{CO} 2, \text { produced }}\right) / n_{\mathrm{b}} \\
S_{\mathrm{CO}}=n_{\mathrm{CO}, \text { produced }} /\left(n_{\mathrm{CO}, \text { produced }}+n_{\mathrm{CO} 2, \text { produced }}\right) \\
S_{\mathrm{CO} 2}=n_{\mathrm{CO} 2, \text { produced }} /\left(n_{\mathrm{CO}, \text { produced }}+n_{\mathrm{CO} 2, \text { produced }}\right)
\end{gathered}
$$

where $C_{\text {Hсно }}$ is the inlet concentration of $\mathrm{HCHO} ; F_{1}$ is the total flow rate at the storage stage; $t_{\mathrm{b}}$ and $V_{\text {cat. }}$ represent the breakthrough time and catalyst volume, respectively. In this work, the breakthrough time was defined as the time when the outlet HCHO concentration reached $10 \%$ of its initial concentration. Furthermore, $\quad n_{\mathrm{CO} \text {,produced }}=\int_{0}^{t_{2}} C_{\mathrm{CO}} F_{2} \mathrm{~d} t, \quad n_{\mathrm{CO}_{2} \text {, produced }}=\int_{0}^{t_{2}} C_{\mathrm{CO}_{2}} F_{2} \mathrm{~d} t$; where $C_{\mathrm{CO}}$ and $C_{\mathrm{CO} 2}$ are the outlet concentrations of $\mathrm{CO}$ and $\mathrm{CO}_{2}$ during the OZCO stage; $F_{2}$ and $t_{2}$ denote the total flow rate and oxidation period during the OZCO stage, respectively. 


\section{Results and discussion}

The cycled storage-OZCO process was performed over $\mathrm{MnO}_{x} / \mathrm{Al}_{2} \mathrm{O}_{3}$ catalysts in this work because the excellent ozone decomposition activity of manganese oxides catalysts is favorable for highly efficient oxidation of HCHO. The breakthrough capacity and OZCO performance of the $\mathrm{MnO}_{x} / \mathrm{Al}_{2} \mathrm{O}_{3}$ catalysts are two important criteria for the cycled storage-OZCO process. The type of manganese precursor and the loading content of the manganese play important roles in the OZCO reaction over $\mathrm{MnO}_{x} / \mathrm{Al}_{2} \mathrm{O}_{3}$ catalysts according to literature reports [19,30,31]; thus, we studied their effects on HCHO storage and the following OZCO performance in this work to screen for an optimal $\mathrm{MnO}_{x} / \mathrm{Al}_{2} \mathrm{O}_{3}$ catalyst. Additionally, the influence of $\mathrm{RH}$ on the storage-OZCO process was also investigated owing to the critical role of $\mathrm{H}_{2} \mathrm{O}$ in practical $\mathrm{HCHO}$ storage and OZCO processes. Unless otherwise specified, the results of the HCHO breakthrough capacity and OZCO performance over all catalysts were obtained with the first storage-OZCO cycle performed at room temperature and a $\mathrm{RH}$ of $50 \%$.

\subsection{Effect of manganese precursor}

It has been recognized that the manganese precursors can affect OZCO reactions over supported $\mathrm{MnO}_{x}$ catalysts because commonly used nitrate and acetate precursors lead to distinct phases and dispersions of $\mathrm{MnO}_{x}$ during preparation [19,30]. For the manganese oxide catalysts used in this work, the manganese precursor not only affected their activity at the OZCO stage, but also influenced the HCHO breakthrough capacity at the storage stage. As a result, supported $\mathrm{MnO}_{x}$ catalysts with a Mn loading of $10 \%$ were prepared with manganese nitrate and manganese acetate as the precursors, denoted as $\mathrm{MN} / \mathrm{Al}_{2} \mathrm{O}_{3}$ and $\mathrm{MA} / \mathrm{Al}_{2} \mathrm{O}_{3}$, respectively. Fig. 3 shows XRD patterns of the $\mathrm{MA} / \mathrm{Al}_{2} \mathrm{O}_{3}$ and $\mathrm{MN} / \mathrm{Al}_{2} \mathrm{O}_{3}$ catalysts. It shows that the diffraction peaks of $\mathrm{Al}_{2} \mathrm{O}_{3}$ were observed for all samples according to the JCPDS data of PDF \#50-0741. For $\mathrm{MA} / \mathrm{Al}_{2} \mathrm{O}_{3}$, peaks were also observed at $32.3^{\circ}, 36.0^{\circ}$, and $59.9^{\circ}$, corresponding to $\mathrm{Mn}_{3} \mathrm{O}_{4}$ (PDF \#24-0734), indicating that the manganese acetate precursor mainly forms a $\mathrm{Mn}_{3} \mathrm{O}_{4}$ phase. On the basis of the Debye-Scherrer equation, we determined the primary particle size

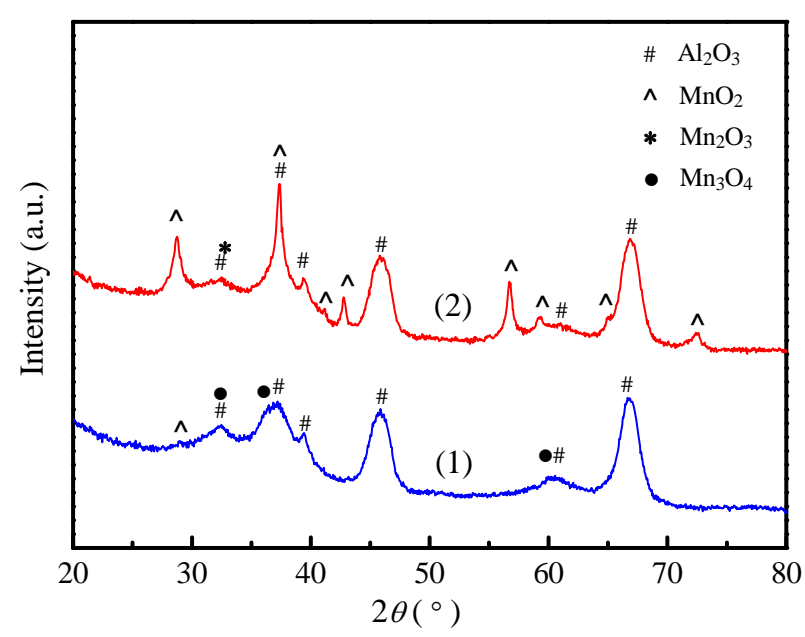

Fig. 3. XRD patterns of the $\mathrm{MA} / \mathrm{Al}_{2} \mathrm{O}_{3}(1)$ and $\mathrm{MN} / \mathrm{Al}_{2} \mathrm{O}_{3}(2)$ catalysts.

to be $6.0 \mathrm{~nm}$ from the diffraction peak at $32.3^{\circ}$. The diffraction peaks of $\mathrm{MnO}_{2}$ (PDF \#24-0735) and $\mathrm{Mn}_{2} \mathrm{O}_{3}$ (PDF \#41-1442) appeared in the XRD results of $\mathrm{MN} / \mathrm{Al}_{2} \mathrm{O}_{3}$, and a primary particle size of approximately $9.5 \mathrm{~nm}$ was calculated from the peak at $28.7^{\circ}$. Thus, the $\mathrm{MA} / \mathrm{Al}_{2} \mathrm{O}_{3}$ contained manganese in a low oxidation state with a smaller particle size than that of $\mathrm{MN} / \mathrm{Al}_{2} \mathrm{O}_{3}$. This result is in agreement with observations reported by Rezaei et al. [30] and Einaga et al. [31].

To determine the chemical binding states of the Mn atoms, the $\mathrm{MA} / \mathrm{Al}_{2} \mathrm{O}_{3}$ and $\mathrm{MN} / \mathrm{Al}_{2} \mathrm{O}_{3}$ catalysts were examined by XPS. The spectra of Mn $2 p$ are shown in Fig. 4, and the distribution of $\mathrm{Mn}^{2+}, \mathrm{Mn}^{3+}$ and $\mathrm{Mn}^{4+}$ species on the catalyst surfaces were calculated and are summarized in Table 1 . In the Mn $2 p$ spectra of $\mathrm{MA} / \mathrm{Al}_{2} \mathrm{O}_{3}$, the peaks at $640.5,642.3$ and $644.5 \mathrm{eV}$ were assigned to $\mathrm{Mn}^{2+}, \mathrm{Mn}^{3+}$ and $\mathrm{Mn}^{4+}$, respectively. However, the $\mathrm{Mn}$ $2 p$ spectra of $\mathrm{MN} / \mathrm{Al}_{2} \mathrm{O}_{3}$, featured only a peak for $\mathrm{Mn}^{3+}$ at 642.1 $\mathrm{eV}$ and peak for $\mathrm{Mn}^{4+}$ at $644.3 \mathrm{eV}$. Although $\mathrm{Mn}^{4+}$ and $\mathrm{Mn}^{3+}$ were observed in both samples, there was a notable difference in their contents. As listed in Table 1, the contents of $\mathrm{Mn}^{3+}$ and $\mathrm{Mn}^{4+}$ in $\mathrm{MA} / \mathrm{Al}_{2} \mathrm{O}_{3}$ were approximately $75 \%$ and $12 \%$, respectively, and $35 \%$ and $65 \%$ in $\mathrm{MN} / \mathrm{Al}_{2} \mathrm{O}_{3}$. These results suggest that the manganese acetate precursor is more favorable for forming $\mathrm{Mn}$ in a lower oxidation state under the same prepara-

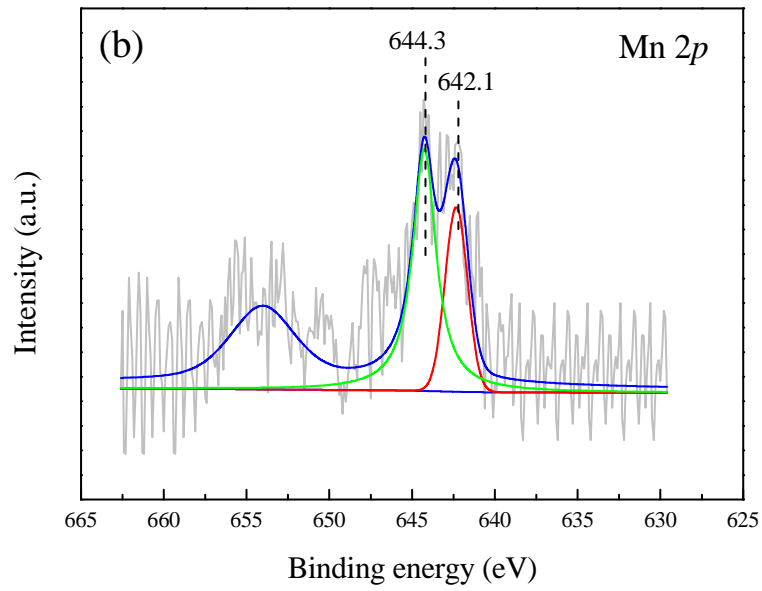

Fig. 4. $\mathrm{Mn} 2 p$ XPS spectra of $\mathrm{MA} / \mathrm{Al}_{2} \mathrm{O}_{3}(\mathrm{a})$ and $\mathrm{MN} / \mathrm{Al}_{2} \mathrm{O}_{3}$ (b) catalysts. 
Table 1

XPS analysis of $\mathrm{MA} / \mathrm{Al}_{2} \mathrm{O}_{3}$ and $\mathrm{MN} / \mathrm{Al}_{2} \mathrm{O}_{3}$ catalysts.

\begin{tabular}{lccccc}
\hline \multirow{2}{*}{ Catalyst } & \multicolumn{3}{c}{$\mathrm{Mn} 2 p_{3 / 2}(\mathrm{eV})$} & $\mathrm{Mn}^{3+} /\left(\mathrm{Mn}^{2+}+\mathrm{Mn}^{3+}\right.$ & $\mathrm{Mn}^{4+} /\left(\mathrm{Mn}^{2+}+\mathrm{Mn}^{3+}\right.$ \\
\cline { 2 - 5 } & $\mathrm{Mn}^{2+}$ & $\mathrm{Mn}^{3+}$ & $\mathrm{Mn}^{4+}$ & $\left.\mathrm{Mn}^{4+}\right)(\mathrm{at} \%)$ & $\left.+\mathrm{Mn}^{4+}\right)(\mathrm{at} \%)$ \\
\hline $\mathrm{MA} / \mathrm{Al}_{2} \mathrm{O}_{3}$ & 640.5 & 642.3 & 644.5 & 75 & 12 \\
$\mathrm{MN} / \mathrm{Al}_{2} \mathrm{O}_{3}$ & - & 642.1 & 644.3 & 35 & 65 \\
\hline
\end{tabular}

tion conditions, which is consistent with the XRD results.

For the storage-OZCO process conducted at a $\mathrm{RH}$ of $50 \%$ and at room temperature, the HCHO breakthrough capacity, carbon balance and selectivity for $\mathrm{CO}_{2}$ over different catalysts are shown in Fig. 5. The oxidation period at the OZCO stage was set to be $50 \mathrm{~min}$ for the $\mathrm{MA} / \mathrm{Al}_{2} \mathrm{O}_{3}$ and $\mathrm{MN} / \mathrm{Al}_{2} \mathrm{O}_{3}$ catalysts, which was sufficient to remove adsorbed species from the $\mathrm{MnO}_{x}$ catalyst surface. As shown in Fig. 5(a), the HCHO breakthrough capacity of $\mathrm{Al}_{2} \mathrm{O}_{3}$ was only $11.6 \mu \mathrm{mol} / \mathrm{mL}$, while the $\mathrm{HCHO}$ breakthrough capacity for $10 \% \mathrm{MA} / \mathrm{Al}_{2} \mathrm{O}_{3}$ and $10 \%$ $\mathrm{MN} / \mathrm{Al}_{2} \mathrm{O}_{3}$ increased to 26.9 and $17.3 \mu \mathrm{mol} / \mathrm{mL}$, respectively. The $\mathrm{Al}_{2} \mathrm{O}_{3}$ supported manganese oxide catalysts possessed much better HCHO breakthrough capacities than that of pure $\mathrm{Al}_{2} \mathrm{O}_{3}$. Because $\mathrm{HCHO}$ was mainly stored on the catalyst surface as partially oxidized $\mathrm{HCOO}^{-}$and $\mathrm{DOM}$ species during storage $[27,32]$, the stronger oxidation ability of the manganese oxides inevitably led to an increase of the HCHO breakthrough capacity when loaded on $\mathrm{Al}_{2} \mathrm{O}_{3}$. Fig. 5(a) also shows that the $\mathrm{MA} / \mathrm{Al}_{2} \mathrm{O}_{3}$ catalyst had a larger $\mathrm{HCHO}$ breakthrough capacity than that of the $\mathrm{MA} / \mathrm{Al}_{2} \mathrm{O}_{3}$ catalyst at the same Mn loading. This may be attributed to the better dispersion of $\mathrm{MA} / \mathrm{Al}_{2} \mathrm{O}_{3}$, which provided more sites for adsorption of HCHO. At the OZCO stage, Fig. 5(b) illustrates that $\mathrm{MA} / \mathrm{Al}_{2} \mathrm{O}_{3}$ achieved a carbon balance of approximately $92 \%$, while the carbon balance values for $\mathrm{MN} / \mathrm{Al}_{2} \mathrm{O}_{3}$ and $\mathrm{Al}_{2} \mathrm{O}_{3}$ were only $78 \%$ and $70 \%$, respectively. The higher carbon balance of the manganese oxide catalysts can be attributed to their excellent ozone decomposition ability, which provided more oxidative species for the OZCO reaction. The low oxidation states of $\mathrm{Mn}$ in $\mathrm{MA} / \mathrm{Al}_{2} \mathrm{O}_{3}$ likely also contributed to the carbon balance results [19]. With respect to the selectivity for products, no $\mathrm{CO}$ was detected during the entire OZCO stage and all samples exhibited $100 \%$ selectivity for $\mathrm{CO}_{2}$ (as shown in Fig. 5(b)). The performance of $\mathrm{MA} / \mathrm{Al}_{2} \mathrm{O}_{3}$ suggested

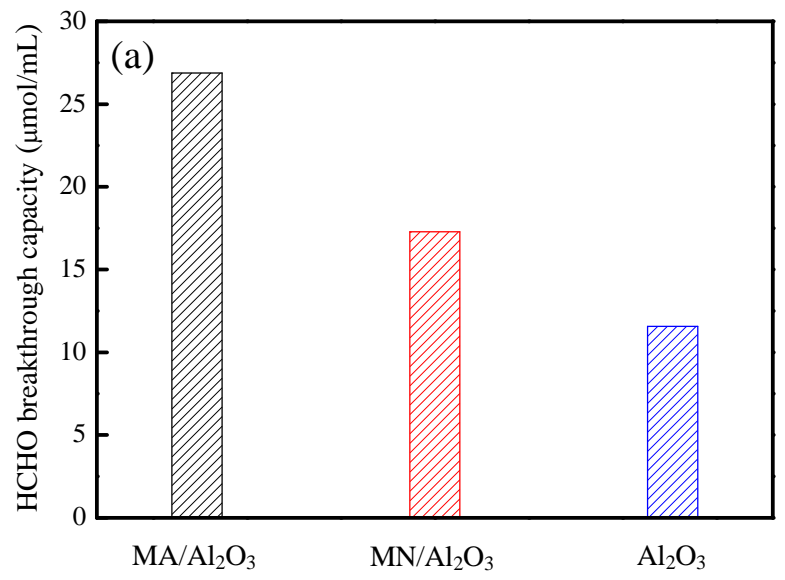

that adsorbed species on the surface during the storage stage were efficiently removed and converted into $\mathrm{CO}_{2}$ at the OZCO stage. This effect is essential to the operation of a cycled storage-OZCO process. Conversely, a poor carbon balance for $\mathrm{MN} / \mathrm{Al}_{2} \mathrm{O}_{3}$ and $\mathrm{Al}_{2} \mathrm{O}_{3}$ means that a large number of adsorption sites remain occupied and might lead to a gradual decrease of the breakthrough capacity over repeated cycling processes.

To further understand the removal process of adsorbed species over the catalysts, the concentration evolution of ozone and $\mathrm{CO}_{x}$ as a function of time were monitored during the OZCO stage. As shown in Fig. 6(a), for $\mathrm{Al}_{2} \mathrm{O}_{3}$ and $\mathrm{MN} / \mathrm{Al}_{2} \mathrm{O}_{3}$, ozone was totally decomposed within the initial $10 \mathrm{~min}$, which corresponded to a rapid increase of the $\mathrm{CO}_{2}$ concentration in Fig. 6(b) (the concentrations of $\mathrm{CO}_{2}$ reached 60 and $75 \mathrm{ppm}$ within $5 \mathrm{~min}$, respectively). This result suggested that the stored HCHO/HCOO-/DOM species on the catalyst surface were effectively removed by ozone during this period. However, further prolonging the treatment time markedly reduced both the ozone conversion and $\mathrm{CO}_{2}$ concentration because the remaining surface species were difficult to completely eliminate. In the case of $\mathrm{MA} / \mathrm{Al}_{2} \mathrm{O}_{3}$, the decomposition of ozone and the release of $\mathrm{CO}_{2}$ exhibited a slow decrease after reaching a maximum (45 ppm of $\mathrm{CO}_{2}$ concentration) during the OZCO stage. This result indicates that the stored species could be eliminated more thoroughly over $\mathrm{MA} / \mathrm{Al}_{2} \mathrm{O}_{3}$ and explains the better carbon balance of the $\mathrm{MA} / \mathrm{Al}_{2} \mathrm{O}_{3}$ catalyst. Figure $6(\mathrm{a})$ shows that the final ozone conversion values over $\mathrm{MA} / \mathrm{Al}_{2} \mathrm{O}_{3}, \mathrm{MN} / \mathrm{Al}_{2} \mathrm{O}_{3}$ and $\mathrm{Al}_{2} \mathrm{O}_{3}$ were $43 \%, 30 \%$ and $14 \%$, respectively. These results reflect the higher ozone decomposition ability of $\mathrm{MA} / \mathrm{Al}_{2} \mathrm{O}_{3}$, which likely originates from the high content of $\mathrm{Mn}$ in a low oxidation state. As reported in the literature [19,33], the decomposition of ozone can be expressed by Eq. (5)-Eq. (7). Manganese in a relatively low oxidation state can transfer electrons to ozone more readily (Eq. (5)), thus facilitating ozone decomposition.

$$
\begin{gathered}
\mathrm{O}_{3}+\mathrm{Mn}^{n+} \rightarrow \mathrm{O}_{2}+\mathrm{O}^{-}+\mathrm{Mn}^{(n+1)+} \\
\mathrm{O}_{3}+\mathrm{O}^{-}+\mathrm{Mn}^{(n+1)+} \rightarrow \mathrm{O}_{2}+\mathrm{O}_{2}^{-}+\mathrm{Mn}^{(n+1)+} \\
\mathrm{O}_{2}^{-}+\mathrm{Mn}^{(n+1)+} \rightarrow \mathrm{O}_{2}+\mathrm{Mn}^{n+}
\end{gathered}
$$

Notably, no CO was produced during the OZCO stage for all catalysts, as shown in Fig. 6(b). On the basis of the above results, it can be inferred that supported manganese oxide cata-

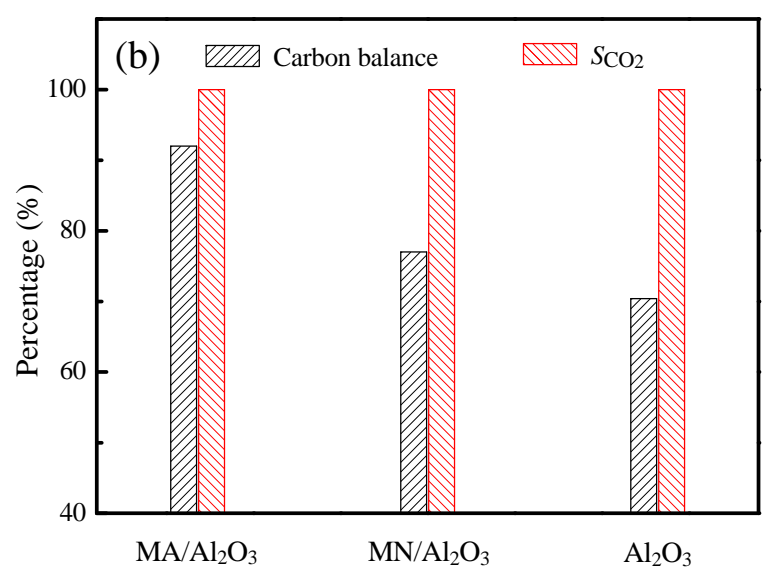

Fig. 5. (a) HCHO breakthrough capacity and (b) carbon balance and selectivity for $\mathrm{CO}_{2}$ over different catalysts. Storage stage: simulated air at 450 $\mathrm{mL} / \mathrm{min}, 50 \% \mathrm{RH}, \mathrm{GHSV}=27000 \mathrm{~h}^{-1}, C_{\mathrm{HCHO}}=15 \mathrm{ppm}$; OZCO stage: simulated air at $250 \mathrm{~mL} / \mathrm{min}, 50 \% \mathrm{RH}, \mathrm{GHSV}=15000 \mathrm{~h}^{-1}, C_{03}=150 \mathrm{ppm}$. 

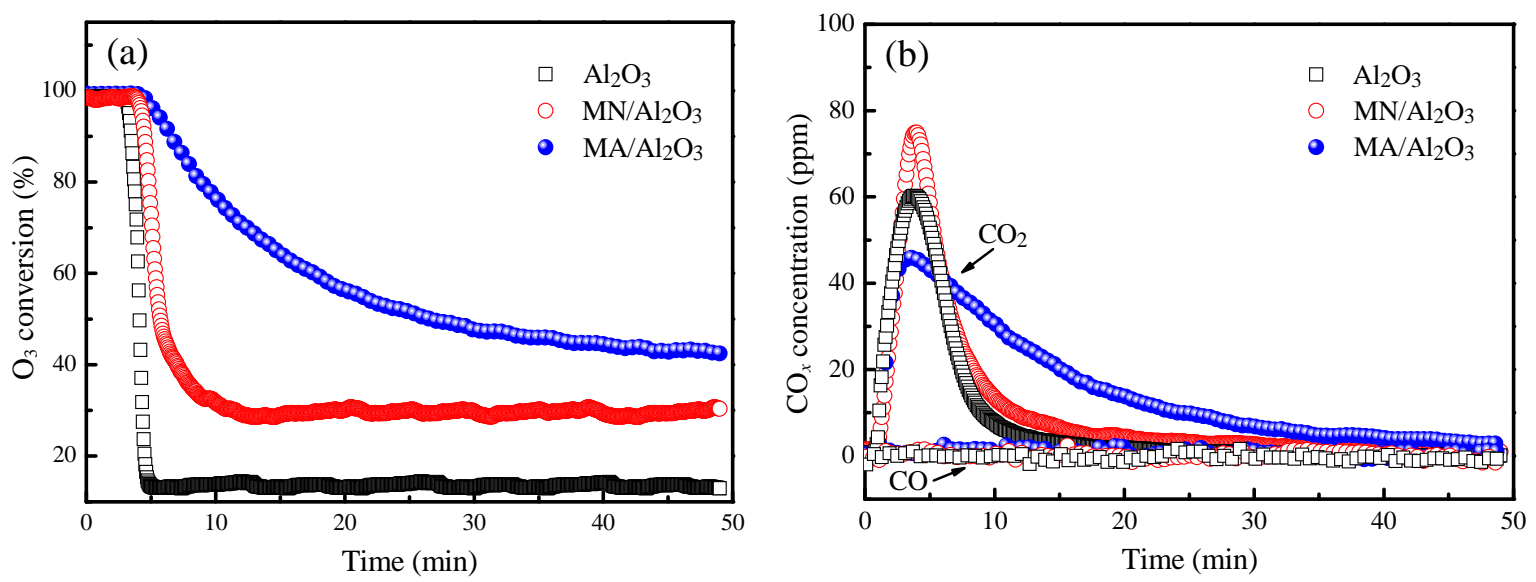

Fig. 6. Ozone conversion (a) and $\mathrm{CO}_{x}$ concentration (b) over different catalysts at the OZCO stage. Catalysts used for the OZCO reaction were taken from the corresponding catalysts after $\mathrm{HCHO}$ storage. Storage stage: simulated air at $450 \mathrm{~mL} / \mathrm{min}, 50 \% \mathrm{RH}, \mathrm{GHSV}=27000 \mathrm{~h}-1, C_{\mathrm{HCHO}}=15 \mathrm{ppm}$, storage period $110 \mathrm{~min}$; OZCO stage: simulated air at $250 \mathrm{~mL} / \mathrm{min}, 50 \% \mathrm{RH}, \mathrm{GHSV}=15000 \mathrm{~h}^{-1}, C_{03}=150 \mathrm{ppm}$.

lysts prepared from manganese acetate precursors show a much better HCHO breakthrough capacity and OZCO performance than that from manganese nitrate. Thus, the $\mathrm{MA} / \mathrm{Al}_{2} \mathrm{O}_{3}$ catalyst was used for the following study.

\subsection{Effects of manganese loading}

The loading of $\mathrm{Mn}$ is another important factor, which affects the HCHO storage and OZCO reaction. A single storage-OZCO cycle was performed over $\mathrm{MA} / \mathrm{Al}_{2} \mathrm{O}_{3}$ catalysts with different $\mathrm{Mn}$ loadings at a $\mathrm{RH}$ of $50 \%$ at room temperature. The $\mathrm{HCHO}$ breakthrough capacity, carbon balance, and selectivity for $\mathrm{CO}_{2}$ over different $\mathrm{MA} / \mathrm{Al}_{2} \mathrm{O}_{3}$ catalysts are shown in Fig. 7. According to Fig. 7(a), during the storage stage, pure $\mathrm{Al}_{2} \mathrm{O}_{3}$ showed the lowest HCHO breakthrough capacity of $11.6 \mu \mathrm{mol} / \mathrm{mL}$. As the Mn loading was increased from $1 \%$ to $10 \%$, the HCHO breakthrough capacity increased monotonically from 16.8 to 26.9 $\mu \mathrm{mol} / \mathrm{mL}$. However, a further increase of the loading to $20 \%$ produced a smaller improvement of $1.7 \mu \mathrm{mol} / \mathrm{mL}$ to the $\mathrm{HCHO}$ breakthrough capacity. Because a high Mn loading can provide more active sites for HCHO adsorption, an enhancement of the HCHO breakthrough capacity with increased loading can be expected. However, a high Mn loading would also decrease the surface area and thus reduce the dispersion of the manganese oxide to some extent. As listed in Table 2, the surface area decreased from 182.37 to $138.02 \mathrm{~m}^{2} / \mathrm{g}$ and the pore volume decreased from 0.83 to $0.56 \mathrm{~cm}^{3} / \mathrm{g}$ for the $\mathrm{MA} / \mathrm{Al}_{2} \mathrm{O}_{3}$ catalysts as the Mn loading was respectively increased from 0 to $20 \%$. A high catalyst loading might even block pores of the $\mathrm{Al}_{2} \mathrm{O}_{3}$ support owing to the formation of large $\mathrm{MnO}_{x}$ particles over the catalyst surface [34]. As a result, the dispersion of manganese oxides on the $\mathrm{Al}_{2} \mathrm{O}_{3}$ surface decreased at high $\mathrm{Mn}$ loading. At the OZCO stage, $100 \% \mathrm{CO}_{2}$ selectivity was obtained at various Mn loadings, as shown in Fig. 7(b). As the Mn loading was increased, the carbon balance first increased to a maximum (92\%) at a loading of $10 \%$ and then started to decrease for further increases of loading. This decrease was likely because the $\mathrm{MA} / \mathrm{Al}_{2} \mathrm{O}_{3}$ with a $10 \% \mathrm{Mn}$ loading possessed sufficient active sites to enable the OZCO reaction and simultaneously provide an appropriate $\mathrm{MnO}_{x}$ dispersion. The effects of the pre-
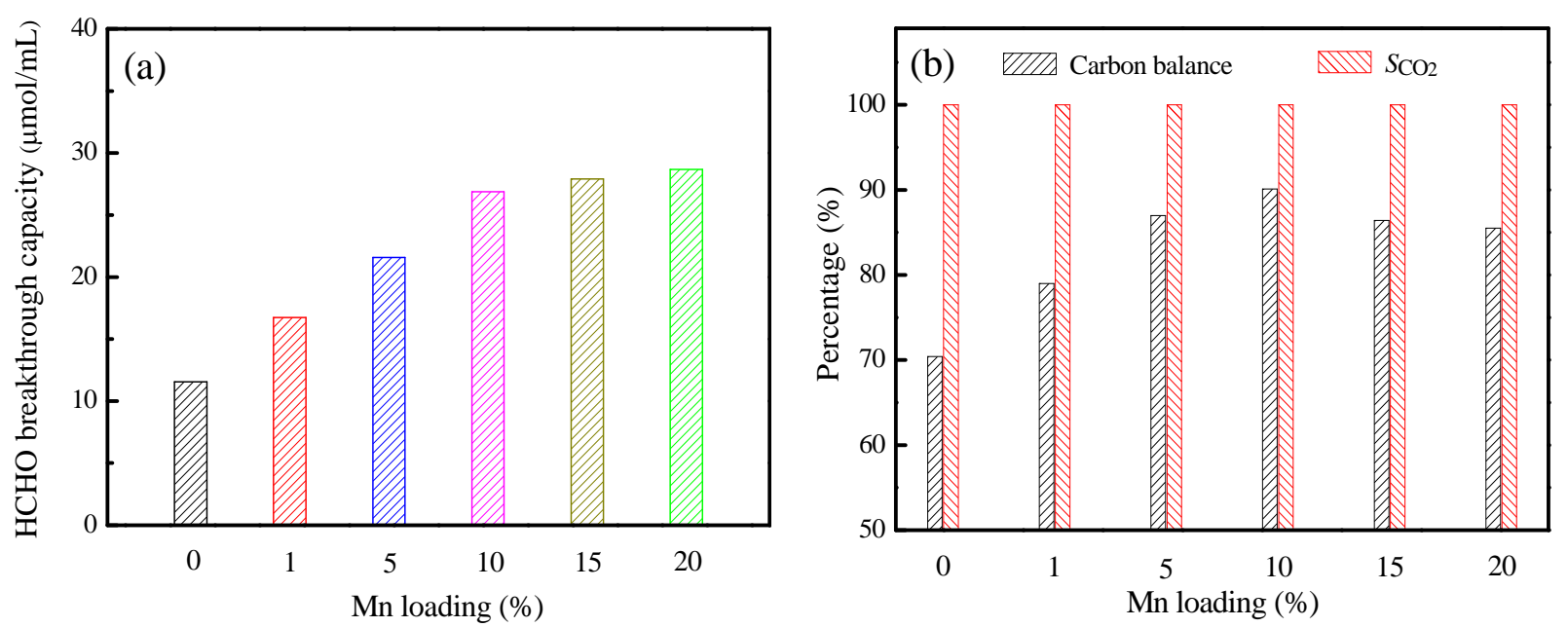

Fig. 7. (a) $\mathrm{HCHO}$ breakthrough capacity and (b) carbon balance and selectivity for $\mathrm{CO}_{2}$ over $\mathrm{MA} / \mathrm{Al}_{2} \mathrm{O}_{3}$ catalysts with various $\mathrm{Mn}$ loadings. Storage stage: simulated air at $450 \mathrm{~mL} / \mathrm{min}, 50 \% \mathrm{RH}, \mathrm{GHSV}=27000 \mathrm{~h}^{-1}, C_{\mathrm{HCHO}}=15 \mathrm{ppm}$; OZCO stage: simulated air at $250 \mathrm{~mL} / \mathrm{min}, 50 \% \mathrm{RH}, \mathrm{GHSV}=15000$ $\mathrm{h}^{-1}, C_{03}=150 \mathrm{ppm}$. 
Table 2

Specific surface area and pore volume of catalysts with various Mn loadings.

\begin{tabular}{lcc}
\hline Catalyst & Surface area $\left(\mathrm{m}^{2} / \mathrm{g}\right)$ & Pore volume $\left(\mathrm{cm}^{3} / \mathrm{g}\right)$ \\
\hline$\gamma-\mathrm{Al}_{2} \mathrm{O}_{3}$ & 182.37 & 0.83 \\
$1 \% \mathrm{MA} / \mathrm{Al}_{2} \mathrm{O}_{3}$ & 180.30 & 0.82 \\
$5 \% \mathrm{MA} / \mathrm{Al}_{2} \mathrm{O}_{3}$ & 170.26 & 0.70 \\
$10 \% \mathrm{MA} / \mathrm{Al}_{2} \mathrm{O}_{3}$ & 166.66 & 0.69 \\
$15 \% \mathrm{MA} / \mathrm{Al}_{2} \mathrm{O}_{3}$ & 150.41 & 0.60 \\
$20 \% \mathrm{MA} / \mathrm{Al}_{2} \mathrm{O}_{3}$ & 138.02 & 0.56 \\
\hline
\end{tabular}

cursor and $\mathrm{Mn}$ loading on the $\mathrm{MnO}_{x} / \mathrm{Al}_{2} \mathrm{O}_{3}$ catalysts indicated that $10 \% \mathrm{MA} / \mathrm{Al}_{2} \mathrm{O}_{3}$ was the optimal catalyst loading for cycled HCHO storage-OZCO processes.

\subsection{Effects of relative humidity}

According to our previous works [28,29], RH plays an important role in the storage-discharge plasma catalytic process. In this study, the effects of RH on $\mathrm{HCHO}$ breakthrough capacity and OZCO performance on $\mathrm{MA} / \mathrm{Al}_{2} \mathrm{O}_{3}$ were investigated and the corresponding results are shown in Fig. 8. Owing to the competitive adsorption between moisture and HCHO over the $\mathrm{MA} / \mathrm{Al}_{2} \mathrm{O}_{3}$ surface, the presence of $\mathrm{H}_{2} \mathrm{O}$ inevitably led to a reduction of the HCHO breakthrough capacity. As observed from Fig. 8(a), during the storage stage, the HCHO breakthrough capacity was substantially reduced from 96.4 to $16.5 \mu \mathrm{mol} / \mathrm{mL}$ when the RH was switched from $0 \%$ to $80 \%$. Conversely, the increase of RH had a positive effect on the OZCO stage. As shown in Fig. 8(b), $\mathrm{CO}_{2}$ selectivities of $100 \%$ were achieved over $\mathrm{MA} / \mathrm{Al}_{2} \mathrm{O}_{3}$ at various $\mathrm{RH}$ conditions, while the carbon balance showed a remarkable improvement as the RH was increased. The carbon balance was only $15 \%$ when dry gas was used during the OZCO stage; however, the value increased to $94 \%$ as the RH was increased to $80 \%$. This result indicates that the presence of $\mathrm{H}_{2} \mathrm{O}$ resulted in a more complete oxidative removal of surface species stored on the $\mathrm{MA} / \mathrm{Al}_{2} \mathrm{O}_{3}$. The TPO analyses for the $\mathrm{MA} / \mathrm{Al}_{2} \mathrm{O}_{3}$ catalysts applied at different $\mathrm{RH}$ during the OZCO stage also supported this interpretation. From the TPO profile shown in Fig. 8(c), two $\mathrm{CO}_{2}$ peaks occurred at approximately 90 and $200{ }^{\circ} \mathrm{C}$, which could be assigned to oxidation of surface $\mathrm{HCHO} / \mathrm{HCOO}^{-}$species and the decomposition of carbonate species, respectively [22]. As the RH was increased, the first peak shifted to a low temperature range and its area decreased slightly, indicating that the presence of $\mathrm{H}_{2} \mathrm{O}$ during the OZCO stage reduced the accumulation of surface $\mathrm{HCHO} / \mathrm{HCOO}^{-}$species and enabled them to be removed more easily. More importantly, the carbonate species on the $\mathrm{MA} / \mathrm{Al}_{2} \mathrm{O}_{3}$ surface showed a marked decrease as the $\mathrm{RH}$ increased (as shown in Fig. 8(c)). This result suggested that the HCHO adsorbed during the storage stage could be largely eliminated at high $\mathrm{RH}$, and thus facilitated a good carbon balance results during the OZCO stage. The positive effects of $\mathrm{RH}$ on the OZCO process indicate that a more favorable oxidation pathway for HCHO became available in the humid gas stream. According to our previous work [22], carbonate species gradually accumulated during the OZCO reaction in the dry air stream (as shown in Fig. 8(c)), which could have contributed to the poor carbon balance in this study. However, in a humid air stream, $\mathrm{OH}$ radicals formed from ozone and the moisture facilitated oxidization of $\mathrm{HCHO}$ to unstable bicarbonate species rather than carbonate species. These bicarbonate species could readily decompose to release $\mathrm{CO}_{2}$. Therefore, a greatly reduced amount of carbonate species on the catalyst surface and excellent carbon balance were obtained during the OZCO stage at high $\mathrm{RH}$. Considering the much higher $\mathrm{H}_{2} \mathrm{O}$ concentration than that of HCHO in indoor air, a RH of 50\% was applied to the cycled storage-OZCO process.
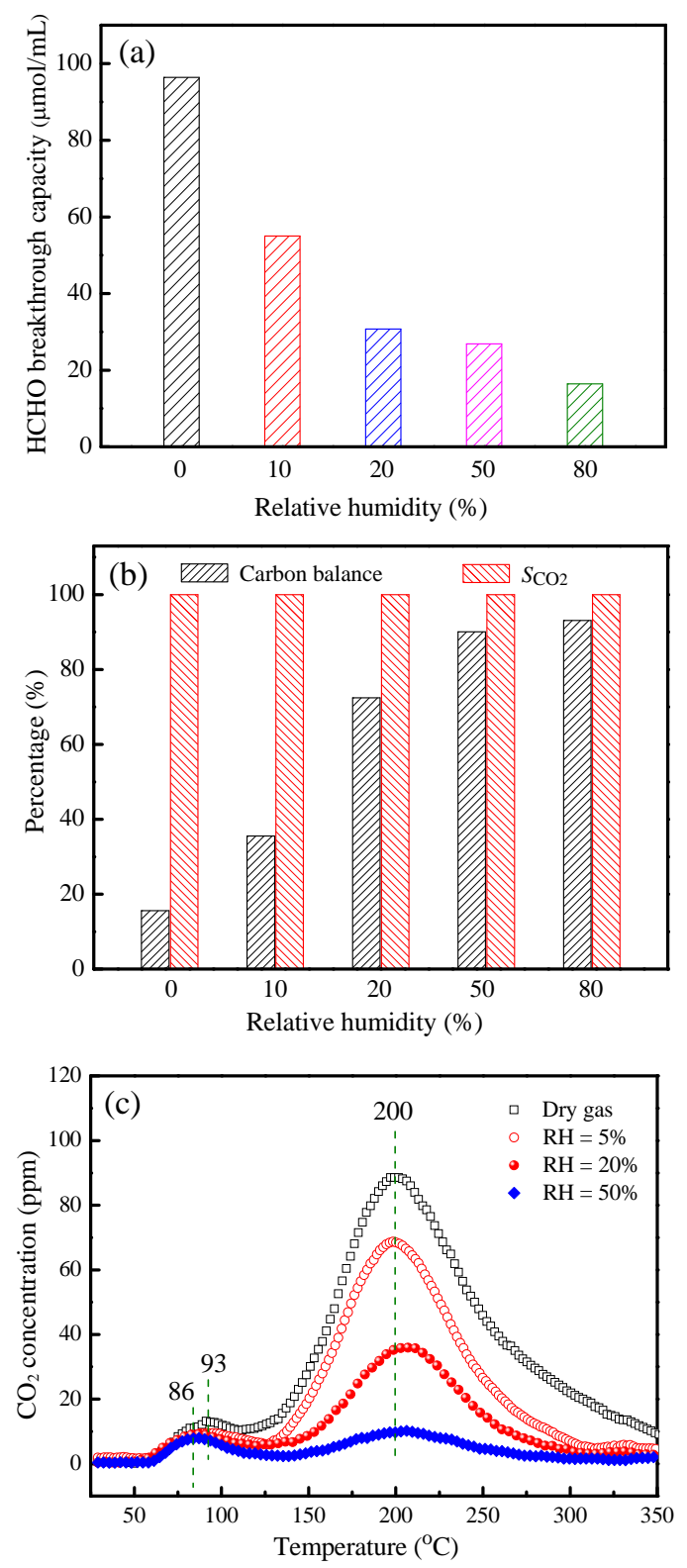

Fig. 8. (a) HCHO breakthrough capacity, (b) carbon balance and selectivity of $\mathrm{CO}_{2}$ over $10 \% \mathrm{MA} / \mathrm{Al}_{2} \mathrm{O}_{3}$ catalysts at various $\mathrm{RH}$ values, and (c) TPO profiles for $\mathrm{MA} / \mathrm{Al}_{2} \mathrm{O}_{3}$ catalysts after one $\mathrm{HCHO}$ storage-OZCO cycle in dry gas at $\mathrm{RH}$ values of $5 \%, 20 \%$ and $50 \%$, respectively. Storage stage simulated air at $450 \mathrm{~mL} / \mathrm{min}, \mathrm{GHSV}=27000 \mathrm{~h}^{-1}, C_{\mathrm{HCHO}}=15 \mathrm{ppm} ;$ OZCO stage: simulated air at $250 \mathrm{~mL} / \mathrm{min}, \mathrm{GHSV}=15000 \mathrm{~h}^{-1}, C_{03}=150 \mathrm{ppm}$; TPO conditions: flow rate of the simulated air $100 \mathrm{~mL} / \mathrm{min}$, heating rate $=5^{\circ} \mathrm{C} / \mathrm{min}$. 


\subsection{Cycled storage-OZCO process for removal of HCHO at low concentration}

In the above-mentioned experiments, $\mathrm{HCHO}$ storage and the following OZCO were performed over $\mathrm{Al}_{2} \mathrm{O}_{3}$ supported manganese oxides catalysts for the purpose of screening optimal catalysts and parameters for a cycled process. To test the practicality of this proposed process, four HCHO storage-OZCO cycles were conducted over the selected $10 \% \mathrm{MA} / \mathrm{Al}_{2} \mathrm{O}_{3}$ catalyst at room temperature and a $\mathrm{RH}$ of $50 \%$. As shown in Fig. 9(a), 15 ppm HCHO in a humid simulated air stream was adsorbed by the $\mathrm{MA} / \mathrm{Al}_{2} \mathrm{O}_{3}$ catalyst during the storage stage. The breakthrough time remained almost constant at 110 min over the
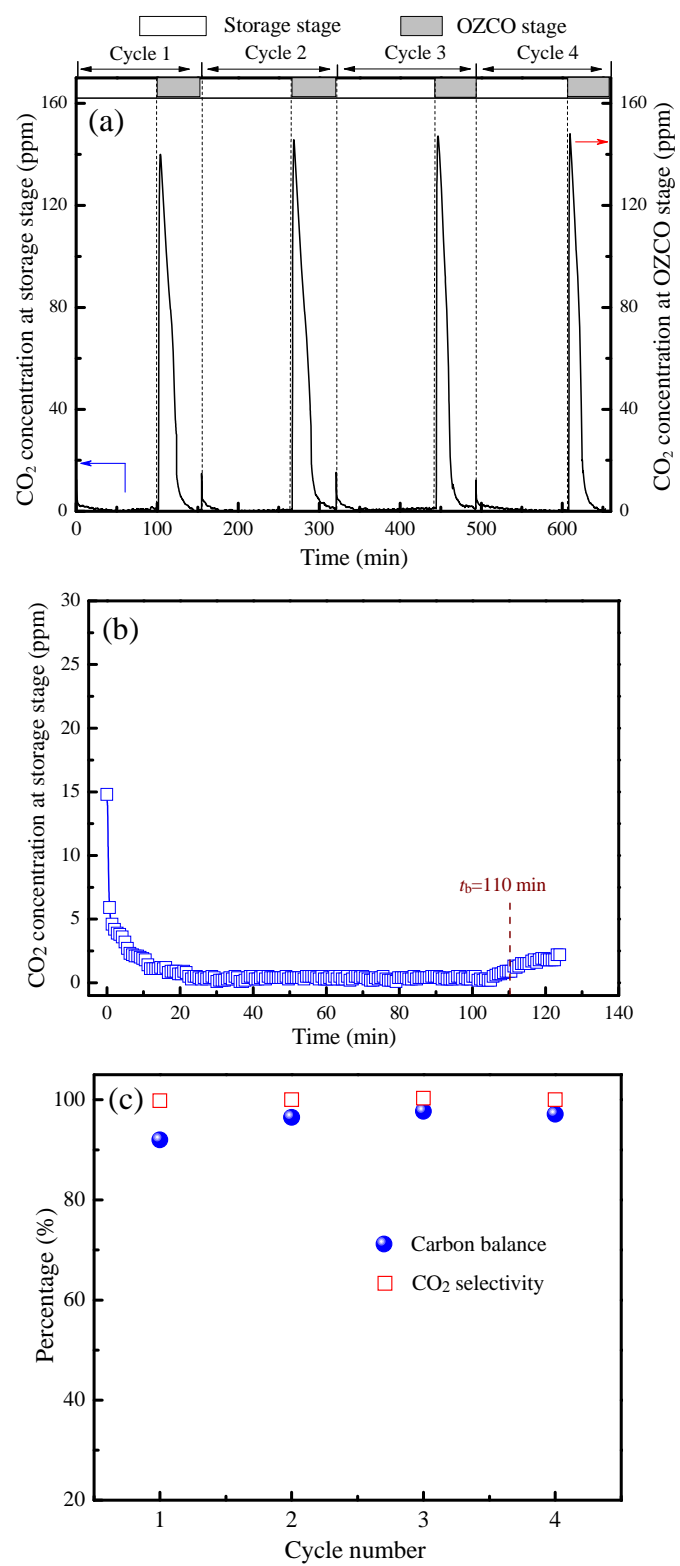

Fig. 9. Concentrations of $\mathrm{CO}_{2}$ at storage and OZCO stages (a), typical storage curve of $\mathrm{HCHO}$ (b) and carbon balance and $\mathrm{CO}_{2}$ selectivity (c) in four storage-OZCO cycles over $10 \% \mathrm{MA} / \mathrm{Al}_{2} \mathrm{O}_{3}$ catalyst. Storage stage: simulated air at $450 \mathrm{~mL} / \mathrm{min}, 50 \% \mathrm{RH}, \mathrm{GHSV}=27000 \mathrm{~h}^{-1}, C_{\mathrm{HCH}}=15$ ppm; OZCO stage: simulated air at $250 \mathrm{~mL} / \mathrm{min}, 50 \% \mathrm{RH}, \mathrm{GHSV}=$ $15000 \mathrm{~h}^{-1}, C_{03}=150 \mathrm{ppm}$. four cycles, indicating the good stability of the $\mathrm{MA} / \mathrm{Al}_{2} \mathrm{O}_{3}$ catalyst during the cycled storage-OZCO processes. Furthermore, considering that a much lower concentration of HCHO is typically present in indoor air (at the ppb level), much longer breakthrough times might be expected. For the $150 \mathrm{ppm}$ ozone treatment during the OZCO period, the stored $\mathrm{HCHO} \mathrm{HCOO}^{-}$ species were rapidly oxidized and released as $\mathrm{CO}_{2}$ and $\mathrm{H}_{2} \mathrm{O}$. Thus, an intense $\mathrm{CO}_{2}$ peak with a maximum concentration of about 160 ppm was observed during this stage. The OZCO stage lasted for approximately $50 \mathrm{~min}$ of each cycle. It should be noted here that a $\mathrm{CO}_{2}$ release occurred at the beginning of each HCHO storage stage. Fig. 9(b) shows a typical storage curve of $\mathrm{HCHO}$ over the $\mathrm{MA} / \mathrm{Al}_{2} \mathrm{O}_{3}$ catalyst at $50 \% \mathrm{RH}$. The $\mathrm{CO}_{2}$ concentration rapidly increased to approximately $15 \mathrm{ppm}$ when switching to the HCHO storage stage, then decreased to 1.4 ppm within 10 min and subsequently exhibited very low values $(<0.4 \mathrm{ppm})$ until the breakthrough $(\sim 1.5 \mathrm{ppm})$ at $110 \mathrm{~min}$. The extremely low $\mathrm{CO}_{2}$ concentration $(\sim 0 \mathrm{ppm})$ after its rapid release during the storage stage suggested that the HCHO was completely oxidized to $\mathrm{CO}_{2}$ or adsorbed to catalyst surface at this stage. The initial $\mathrm{CO}_{2}$ release could be attributed to reactions occurring between active oxygen species on the $\mathrm{MA} / \mathrm{Al}_{2} \mathrm{O}_{3}$ surface and the adsorbed HCHO. However, as the surface active oxygen species were gradually consumed, adsorbed $\mathrm{HCHO}$ cannot be completely oxidized to $\mathrm{CO}_{2}$ and negligible amounts of $\mathrm{CO}_{2}$ were detected. In this work, we also consider the completely oxidized HCHO during the storage stage in the HCHO breakthrough capacity because the conversion of adsorbed $\mathrm{HCHO}$ into $\mathrm{CO}_{2}$ does not contribute to pollution.

The carbon balance and selectivity for $\mathrm{CO}_{2}$ in these four cycles are illustrated in Fig. 9(c). The selectivity for $\mathrm{CO}_{2}$ conversion in the four cycles was $100 \%$, and no CO was detected over the entire process, indicating that regeneration of the $\mathrm{MA} / \mathrm{Al}_{2} \mathrm{O}_{3}$ catalyst by ozone didn't cause secondary pollution from $\mathrm{CO}$. Fig. 9 (c) also shows that the carbon balance values of these four cycles were $92 \%, 97 \%, 98 \%$ and $97 \%$, respectively. The carbon balance values of cycles 2-4 were better than that of the first cycle and much closer to $100 \%$. This result suggests that the $\mathrm{HCHO}$ storage-OZCO process over the $\mathrm{MA} / \mathrm{Al}_{2} \mathrm{O}_{3}$ catalyst stabilized after the first cycle, and the adsorbed HCHO was completely removed by ozone at room temperature. Here, the adsorption of HCHO on the fresh catalysts likely formed strongly adhered surface species at certain sites, which could not be removed by the OZCO reaction at room temperature. This blocking of sites resulted in a relatively low carbon balance for the first storage-OZCO cycle. Fortunately, once these species were formed at the first storage stage, the $\mathrm{MA} / \mathrm{Al}_{2} \mathrm{O}_{3}$ catalyst exhibited a carbon balance of almost $100 \%$ in the following storage-OZCO cycles.

In this work, the species formed on the $\mathrm{MA} / \mathrm{Al}_{2} \mathrm{O}_{3}$ catalyst surface might be attributed to mono- or bidentate carbonate species which possess a relatively high decomposition temperature $\left(200^{\circ} \mathrm{C}\right)$ as illustrated in Fig. 8(c). The DRIFT spectra clearly showed variation of surface species over the catalysts during cycling of $\mathrm{HCHO}$ storage-OZCO process. Fig. 10 shows the DRIFT spectra of the $\mathrm{MA} / \mathrm{Al}_{2} \mathrm{O}_{3}$ catalyst after $\mathrm{HCHO}$ adsorption and OZCO in the first and second cycles. Owing to the ad- 


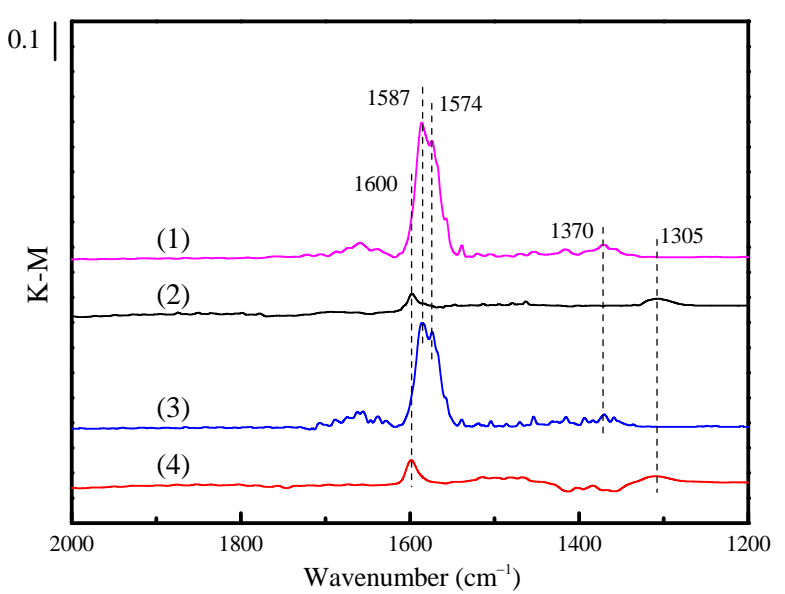

Fig. 10. DRIFT spectra of $10 \% \mathrm{MA} / \mathrm{Al}_{2} \mathrm{O}_{3}$ catalyst after (1) $\mathrm{HCHO}$ adsorption and (2) OZCO in the first storage-OZCO cycle, (3) HCHO adsorption and (4) OZCO in the second storage-OZCO cycle. Storage stage: simulated air at $200 \mathrm{~mL} / \mathrm{min}, 50 \% \mathrm{RH}, C_{\text {нсно }}=15 \mathrm{ppm}$; OZCO stage: simulated air at $200 \mathrm{~mL} / \mathrm{min}, 50 \% \mathrm{RH}, C_{03}=150 \mathrm{ppm}$.

sorption and partial oxidation of HCHO on the catalyst surface, a fresh sample after HCHO adsorption (curve (1)) showed intense IR peaks from formate species at 1587, 1574, and 1370 $\mathrm{cm}^{-1}$ [27]. After OZCO (curve (2)), the bands from adsorbed formate species disappeared, while new IR peaks from surface carbonate species appeared at 1600 and $1305 \mathrm{~cm}^{-1}$ with a relatively weak intensity [35,36]. These two peaks could not be removed even with a long OZCO period $(1 \mathrm{~h})$, suggesting that they corresponded to strongly adhered surface species on the $\mathrm{MA} / \mathrm{Al}_{2} \mathrm{O}_{3}$ catalyst. In the second cycle, the IR bands of the formate species appeared again after HCHO adsorption (curve (3)). Notably, the IR bands of the carbonate species after OZCO in the second cycle (curve (4)) exhibited a similar intensity to that of the first cycle. This result indicates that strongly adhered carbonate species were mainly formed during the first cycle and did not accumulate with increasing cycles of the HCHO storage-OZCO process. This finding might explain the excellent carbon balance obtained after the first HCHO storage-OZCO cycle.

To directly compare the ozone utilization of our novel storage-OZCO process and a conventional OZCO process, the ozone flow rates as a function of time for these two processes are illustrated in Fig. 11. According to our continuous OZCO experiments, at least $90 \mathrm{ppm}$ of ozone is required to completely eliminate $15 \mathrm{ppm}$ HCHO from $450 \mathrm{~mL} / \mathrm{min}$ simulated air at $\mathrm{RH}$ of $50 \%$. Thus, an ozone flow rate of approximately $40.5 \mu \mathrm{L} / \mathrm{min}$ is required for the conventional OZCO process and $37.5 \mu \mathrm{L} / \mathrm{min}$ for the OZCO stage of our new process. From Fig. 11, we calculated that, over the $220 \mathrm{~min}$ reaction period, $8910 \mu \mathrm{L}$ of ozone would be consumed by the conventional OZCO process. Using our novel process, we could eliminate the same amount of HCHO from the simulated air with two HCHO storage-OZCO cycles, consuming only $3750 \mu \mathrm{L}$ of ozone. Thus, the new process can reduce ozone consumption by almost $60 \%$ compared with the conventional OZCO process. Furthermore, only $40 \%$ of the ozone was decomposed during the continuous OZCO reaction, which could lead to secondary pollution because of the

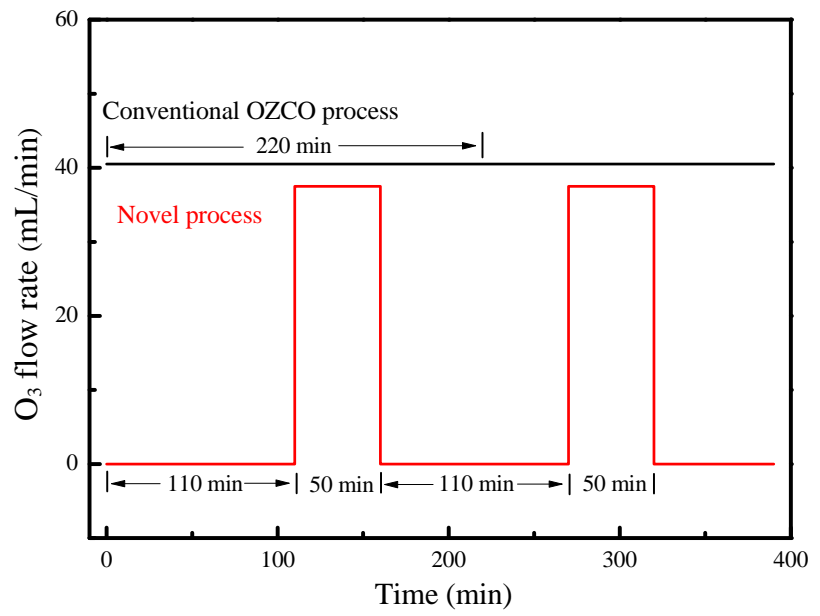

Fig. 11. Schematic diagram comparing of ozone utilization over $10 \%$ $\mathrm{MA} / \mathrm{Al}_{2} \mathrm{O}_{3}$ catalyst of novel storage-OZCO process and the conventional OZCO process.

continuous exhaust of incompletely decomposed ozone into the air. Conversely, the novel process not only exhibited a higher ozone conversion (as shown in Fig. 6(a)) but also possessed a much shorter OZCO period, which could alleviate the effects of secondary pollution from undecomposed ozone. Furthermore, the OZCO stage could be further shortened in a practical HCHO storage-OZCO process because the majority of adsorbed HCHO was removed within the first $30 \mathrm{~min}$ of the process (as shown in Fig. 6(b)). This suggests that both ozone consumption and secondary pollution from undecomposed ozone in the novel process could be further reduced.

In view of the excellent performance of the cycled HCHO storage-OZCO processes over supported manganese oxide catalysts in the preliminary experiments, we believe that the storage-OZCO process is a promising approach for practical HCHO elimination and might be developed into a reliable and economical indoor air purification technique.

\section{Conclusions}

A novel process of cycled storage-OZCO was applied to low concentration $\mathrm{HCHO}$ removal over $\mathrm{MnO}_{x} / \mathrm{Al}_{2} \mathrm{O}_{3}$ catalysts at room temperature. The effects of the manganese precursor and loading on the storage-OZCO process were investigated to screen out optimal $\mathrm{MnO}_{x} / \mathrm{Al}_{2} \mathrm{O}_{3}$ catalysts. Characterization by XRD and XPS indicated that the manganese oxide catalysts prepared from acetate precursors showed a smaller $\mathrm{MnO}_{x}$ particle size and possessed a $\mathrm{Mn}^{3+}$ content of $75 \%$. These factors contributed to their good performance in $\mathrm{HCHO}$ storage and OZCO compared with the performance of a catalyst formed from a nitrate precursor. The high ozone decomposition ability and excellent carbon balance for the $\mathrm{MA} / \mathrm{Al}_{2} \mathrm{O}_{3}$ catalyst was attributed to a high content of $\mathrm{Mn}$ in a low oxidation state. Increasing the $\mathrm{Mn}$ loading of the $\mathrm{MA} / \mathrm{Al}_{2} \mathrm{O}_{3}$ catalyst had a positive effect on the HCHO breakthrough capacity, while a $10 \% \mathrm{Mn}$ loading exhibited the best carbon balance during the OZCO stage. The competitive adsorption of $\mathrm{H}_{2} \mathrm{O}$ with $\mathrm{HCHO}$ led to a gradual decrease of the breakthrough capacity as RH increased. 
However, at high RH ( $\geq 50 \%$ ) an excellent carbon balance at the OZCO stage was achieved owing to a favorable oxidation pathway for HCHO.

Four HCHO storage-OZCO cycles were conducted over the $10 \% \mathrm{MA} / \mathrm{Al}_{2} \mathrm{O}_{3}$ catalyst at room temperature to test the feasibility of the cycled storage-OZCO process. We showed that a low concentration of HCHO could be efficiently and steadily eliminated over four-cycles of the storage-OZCO process without forming secondary pollution from CO. Our new approach represents a $60 \%$ saving of ozone usage compared with that of continuous OZCO reactions. Thus, we successfully demonstrated that cycled storage-OZCO processes are an economical, reliable and promising indoor air purification technique.

\section{Acknowledgments}

We thank Andrew Jackson, PhD, from Liwen Bianji, Edanz Group China (www.liwenbianji.cn/ac), for editing the English text of a draft of this manuscript.

\section{References}

[1] B. F. Yu, Z. B. Hu, M. Liu, H. L. Yang, Q. X. Kong, Y. H. Liu, Int. J. Refrig., 2009, 32, 3-20.

[2] Y. Sekine, Atmos. Environ., 2002, 36, 5543-5547.

[3] B. Y. Bai, Q. Qiao, J. H. Li, J. M. Hao, Chin. J. Catal., 2016, 37, 102-122.

[4] B. B. Chen, X. B. Zhu, Y. D. Wang, L. M. Yu, C. Shi, Chin. J. Catal., 2016, 37, 1729-1737.

[5] M. Wang, L. X. Zhang, W. M. Huang, T. P. Xiu, C. G. Zhuang, J. L. Shi, Chem. Eng. J., 2017, 320, 667-676.

[6] X. Q. Deng, J. L. Liu, X. S. Li, B. Zhu, X. B. Zhu, A. M. Zhu, Catal. Today, 2017, 281, 630-635.

[7] P. F. Fu, P. Y. Zhang, Chin. J. Catal., 2014, 35, 210-218.

[8] H. X. Ding, A. M. Zhu, F. G. Lu, Y. Xu, J. Zhang, X. F. Yang, J. Phys. D,
2006, 39, 3603-3608.

[9] X. B. Zhu, X. Gao, R. Qin, Y. X. Zeng, R. Y. Qu, C. H. Zheng, X. Tu, Appl. Catal. B, 2015, 170-171, 293-300.

[10] X. F. Tang, Y. G. Li, X. M. Huang, Y. D. Xu, H. Q. Zhu, J. G. Wang, W. J. Shen, Appl. Catal. B, 2006, 62, 265-273.

[11] H. F. Li, N. Zhang, P. Chen, M. F. Luo, J. Q. Lu, Appl. Catal. B, 2011, $110,279-285$.

[12] C. B. Zhang, H. He, K. I. Tanaka, Appl. Catal. B, 2006, 65, 37-43.

[13] H. B. Huang, Y. Xu, Q. Y. Feng, D. Y. Leung, Catal. Sci. Technol., 2015, 5, 2649-2669.

[14] H. S. Liang, H. C. Wang, M. B. Chang, Ind. Eng. Chem. Res., 2011, 50, 13322-13329.

[15] M. Stoyanova, P. Konova, P. Nikolov, A. Naydenov, S. Christoskova, D. Mehandjiev, Chem. Eng. J., 2006, 122, 41-46.

[16] H. B. Huang, X. G. Ye, W. J. Huang, J. D. Chen, Y. Xu, M. Y. Wu, Q. M. Shao, Z. R. Peng, G. C. Ou, J. X. Shi, X. Feng, Q. Y. Feng, H. L. Huang, P. Hu, D. Y. C. Leung, Chem. Eng. J., 2015, 264, 24-31.

[17] H. Einaga, S. Futamura, J. Catal., 2004, 227, 304-312.

[18] H. Einaga, Y. Teraoka, A. Ogata, J. Catal., 2013, 305, 227-237.

[19] E. Rezaei, J. Soltan, N. Chen, Appl. Catal. B, 2013, 136-137, 239-247.

[20] C. Y. H. Chao, C. W. Kwong, K. S. Hui, J. Hazard. Mater., 2007, 143, 118-127.

[21] D. Z. Zhao, T. Y. Ding, X. S. Li, J. L. Liu, C. Shi, A. M. Zhu, Chin. J. Catal., 2012, 33, 396-401.

[22] D. Z. Zhao, C. Shi, X. S. Li, A. M. Zhu, B. W. L. Jang, J. Hazard. Mater., 2012, 239-240, 362-369.

[23] S. T. Oyama, Catal. Rev. Sci. Eng., 2000, 42, 279-322.

[24] Y. Liu, X. S. Li, C. Shi, J. L. Liu, A. M. Zhu, B. W. L. Jang, Catal. Sci. Technol., 2014, 4, 2589-2598.

[25] H. B. Huang, W. J. Huang, Y. Xu, X. G. Ye, M. Y. Wu, Q. M. Shao, G. C. Ou, Z. R. Peng, J. X. Shi, J. D. Chen, Q. Y. Feng, Y. J. Zan, H. L. Huang, P. Hu, Catal. Today, 2015, 258, 627-633.

[26] E. Rezaei, J. Soltan, N. Chen, J. Lin, Chem. Eng. J., 2013, 214, 219-228.

[27] C. Shi, B. B. Chen, X. S. Li, M. Crocker, Y. Wang, A. M. Zhu, Chem. Eng. J., 2012, 200-202, 729-737.

\section{Graphical Abstract}

Chin. J. Catal., 2017, 38: 1759-1769 doi: 10.1016/S1872-2067(17)62890-0

\section{A novel process of ozone catalytic oxidation for low concentration formaldehyde removal}

Bin Zhu, Xiao-Song Li, Peng Sun, Jing-Lin Liu, Xiao-Yuan Ma, Xiaobing Zhu *, Ai-Min Zhu * Dalian Maritime University; Dalian University of Technology
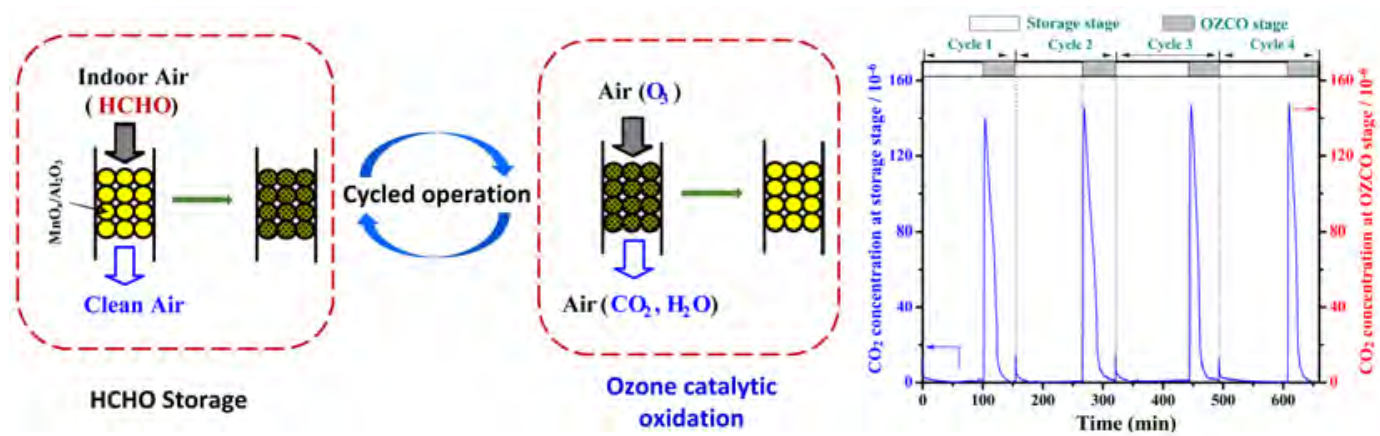

A promising novel process of cycled storage-ozone catalytic oxidation (OZCO) was successfully employed to remove low concentration formaldehyde ( $\mathrm{HCHO}$ ) from air over the optimal $\mathrm{MnO}_{x} / \mathrm{Al}_{2} \mathrm{O}_{3}$ catalyst (manganese acetate precursor and $10 \mathrm{wt} \% \mathrm{Mn}$ loading) at room temperature. 
[28] D. Z. Zhao, X. S. Li, C. Shi, H. Y. Fan, A. M. Zhu, Chem. Eng. Sci., 2011, 66, 3922-3929.

[29] H. Y. Fan, C. Shi, X. S. Li, D. Z. Zhao, Y. Xu, A. M. Zhu, J. Phys. D, 2009, 42, 225105.

[30] E. Rezaei, J. Soltan, Chem. Eng. J., 2012, 198-199, 482-490.

[31] H. Einaga, M. Harada, A. Ogata, Catal. Lett., 2009, 129, 422-427.

[32] C. B. Zhang, X. Y. Shi, H. W. Gao, H. He, J. Environ. Sci., 2005, 17, 429-432.
[33] R. Radhakrishnan, S. T. Oyama, J. G. Chen, K. Asakura, J. Phys. Chem. $B, \mathbf{2 0 0 1}, 105,4245-4253$.

[34] Y. Liu, X. S. Li, J. L. Liu, C. Shi, A. M. Zhu, Chin. J. Catal,, 2014, 35, 1465-1474.

[35] C. Laberty, C. Marquez-Alvarez, C. Drouet, P. Alphonse, C. Mirodatos, J. Catal., 2001, 198, 266-276.

[36] F. C. Meunier, D. Tibiletti, A. Goguet, D. Reid, R. Burch, Appl. Catal. A, 2005, 289, 104-112.

\title{
臭氧催化氧化脱除低浓度甲醛的新方法
}

\author{
朱 斌, a,c, 李小松 ${ }^{\mathrm{b}, \mathrm{c}}$, 孙 鹏, , 刘景林 ${ }^{\mathrm{b}, \mathrm{c}}$, 马晓媛 ${ }^{\mathrm{b}, \mathrm{c}}$, 朱晓兵 ${ }^{\mathrm{b}, \mathrm{c}, *}$, 朱爱民, \\ a 大连海事大学船舶防污染测控技术协同创新中心, 辽宁大连 116026 \\ ${ }^{\mathrm{b}}$ 大连理工大学等离子体物理化学实验室, 辽宁大连 116024 \\ ${ }^{\mathrm{C}}$ 大连理工大学氢能与环境催化研究中心, 辽宁大连 116024
}

\begin{abstract}
摘要: 甲醛作为一种典型的室内挥发性有机污染物, 对人体健康危害很大. 目前, 在可用于室内甲醛脱除的诸多方法之中, 臭氧催化氧化法因可于室温下使用廉价的金属氧化物催化剂实现对甲醛的高效脱除, 从而受到了科研工作者的广泛关注. 然而, 考虑到室内甲醛的浓度极低, 且存在着长期缓慢释放的特点, 传统的臭氧催化氧化法应用于实际的室内甲醛脱除不 仅会造成能量的浪费, 而且还易因未完全分解臭氧的连续释放带来二次污染问题.

为了提高臭氧催化氧化脱除甲醛过程的臭氧利用率, 降低能耗, 并有效缓解未分解臭氧引起的二次污染, 本文将一种 循环的甲醛存储-臭氧催化氧化新方法应用于室内低浓度甲醛的脱除. 该新方法包含甲醛存储与臭氧催化氧化两个过程, 在存储阶段低浓度甲醛吸附存储于催化剂表面, 而在臭氧催化氧化阶段臭氧将存储的甲醛氧化为 $\mathrm{CO}_{2}$ 与 $\mathrm{H}_{2} \mathrm{O}$, 并重新释放 催化剂表面的吸附位. 因负载型氧化锰具有优良的臭氧分解能力, 本研究以 $\mathrm{Al}_{2} \mathrm{O}_{3}$ 负载的 $\mathrm{MnO}_{x}$ 为催化剂, 通过研究前驱体 及担载量对甲酫脱除反应的影响, 笁选出了最优的 $\mathrm{MnO}_{x} / \mathrm{Al}_{2} \mathrm{O}_{3}$ 催化剂, 并对相对湿度的影响规律进行了考察, 最后通过低 浓度甲酫存储-臭氧催化氧化循环实验验证了该甲酫臭氧催化氧化新过程的可靠性.

我们采用传统的等体积浸渍法, 基于不同的前驱体制备 $\mathrm{MnO}_{x} / \mathrm{Al}_{2} \mathrm{O}_{3}$ 催化剂. $\mathrm{XRD}$ 表征结果表明, 乙酸锰为前驱体制得 的 $\mathrm{MA} / \mathrm{Al}_{2} \mathrm{O}_{3}$ 催化剂中 $\mathrm{MnO}_{x}$ 相主要为 $\mathrm{Mn}_{3} \mathrm{O}_{4}$ (粒径约为 $6.0 \mathrm{~nm}$ ); 而硝酸锰前驱体所得 $\mathrm{MN} / \mathrm{Al}_{2} \mathrm{O}_{3}$ 催化剂中则含有 $\mathrm{MnO}_{2}$ 与 $\mathrm{Mn}_{2} \mathrm{O}_{3}$ 相, 且其 $\mathrm{MnO}_{x}$ 颗粒粒径较大, 约为 $9.5 \mathrm{~nm}$. XPS测试结果表明, $\mathrm{MA} / \mathrm{Al}_{2} \mathrm{O}_{3}$ 催化剂含有 $\mathrm{Mn}^{2+}, \mathrm{Mn}^{3+}$ 及 $\mathrm{Mn}^{4+}$, 其中 $\mathrm{Mn}^{3+}$ 与 $\mathrm{Mn}^{4+}$ 的含量分别为 $75 \%$ 与 $12 \%$; 而 $\mathrm{MN} / \mathrm{Al}_{2} \mathrm{O}_{3}$ 催化剂则仅含有 $\mathrm{Mn}^{3+}$ 与 $\mathrm{Mn}^{4+}$, 含量分别为 $35 \%$ 与 $65 \%$. 上述XRD与XPS结果相 一致, 说明以乙酸锰为前驱体所得催化剂的分散度较高且易形成低氧化态的Mn. 甲醛存储-臭氧催化氧化实验结果表明, 与 $\mathrm{Al}_{2} \mathrm{O}_{3}$ 及 $\mathrm{MN} / \mathrm{Al}_{2} \mathrm{O}_{3}$ 相比, $\mathrm{MA} / \mathrm{Al}_{2} \mathrm{O}_{3}$ 催化剂具有更高的甲醛存储与催化氧化脱除性能. 基于 $\mathrm{MA} / \mathrm{Al}_{2} \mathrm{O}_{3}$ 催化剂, 不同 $\mathrm{Mn}$ 负载 量下的甲醛存储与臭氧催化氧化实验结果表明, $\mathrm{Mn}$ 负载量为 $10 \mathrm{wt} \%$ 时 $\mathrm{MA} / \mathrm{Al}_{2} \mathrm{O}_{3}$ 的性能最佳. 因而, 进一步的实验中我们 均选用最优的 $10 \mathrm{wt} \% \mathrm{MA} / \mathrm{Al}_{2} \mathrm{O}_{3}$ 为催化剂, 其在 $50 \%$ 相对湿度下的甲醛存储量为 $26.9 \mu \mathrm{mol} / \mathrm{mL}$, 臭氧催化氧化阶段碳平衡为 $92 \%, \mathrm{CO}_{2}$ 选择性为 $100 \%$. 相对湿度的影响结果 $\left(23^{\circ} \mathrm{C}\right)$ 则表明, 由于水分子与甲醛分子间存在着竞争吸附作用, 甲醛存储容 量随相对湿度的增加而降低; 但因相对湿度增加可建立利于甲酫氧化的新途径, 故臭氧催化氧化性能随相对湿度增加而 增强. 综合考虑, $10 \mathrm{wt} \% \mathrm{MA} / \mathrm{Al}_{2} \mathrm{O}_{3}$ 上甲醛存储-臭氧催化氧化的最优相对湿度为 $50 \%$.

为验证所提出新方法的实用性, 我们基于 $10 \mathrm{wt} \% \mathrm{MA} / \mathrm{Al}_{2} \mathrm{O}_{3}$ 开展了甲醛存储-臭氧催化氧化的4次循环实验. 4 次循环实 验中的甲酲存储以及臭氧催化氧化处理的规律可基本保持一致. $50 \%$ 相对湿度下, 低浓度甲醛 $\left(15 \times 10^{-6}\right)$ 在空速为 27000 $\mathrm{h}^{-1}$ 时的穿透时间为 $110 \mathrm{~min}$, 而在臭氧催化氧化阶段 $\left(150 \times 10^{-6}\right.$ 臭氧, 空速 $\left.15000 \mathrm{~h}^{-1}\right)$ 仅需约 $50 \mathrm{~min}$ 即可实现对存储甲醛的氧 化脱除(碳平衡大于 $92 \%, \mathrm{CO}_{2}$ 选择性 $100 \%$ ), 表明该新方法较传统的臭氧催化氧化方法臭氧用量可节省 $60 \%$.
\end{abstract}

关键词: 甲酫脱除; 存储; 臭氧; 催化氧化; 氧化锰催化剂

收稿日期: 2017-06-02. 接受日期: 2017-07-19. 出版日期: 2017-10-05.

*通讯联系人. 电话/传真: (0411)84706094; 电子信箱: xzhu@dlut.edu.cn

\#通讯联系人. 电话/传真: (0411)84706094; 电子信箱: amzhu@dlut.edu.cn

基金来源：国家自然科学基金(21673030); 辽宁省高等教育发展基金(协同创新中心)(20110217004).

本文的英文电子版由Elsevier出版社在ScienceDirect上出版(http://www.sciencedirect.com/science/journal/18722067). 